\title{
Status of microflora on Bt and non - Bt cotton
}

\author{
S. N. AMBHORE AND B. G. BARHATE*
}

Department of Plant Pathology and Agricultural Microbiology, Mahatma Phule Krishi Vidyapeeth, Rahuri, AHEMDNAGAR (M.S.) INDIA

\section{ARITCLE INFO}

Received : 22.03 .2017

Revised : 15.09 .2017

Accepted : 25.09.2017

\section{KEY WORDS :}

Bt cotton, Bacteria, Fungi, Microbial diversity

*Corresponding author:

bgbarhate@gmail.com

\begin{abstract}
:
Transgenic Bt cotton expresses CrylAc protein from Bacillus thuringiensis. The diversity of ectophytic and endophytic fungi and bacteria in roots, stems and leaves from transgenic $(\mathrm{Bt}$ ) and non transgenic (non Bt)cotton was evaluated during 30,60 and 90 DAS to investigate possible non-target effects of genetically modified cotton on microbial communities. Total ten fungal and five bacterial organisms were isolated. This studies shows that the roots, stems and leaves of Bt and non Bt cotton plants harboured endophytes and ectophytes. Although the no.of endophytic and ectophytic species isolated from the two types of plant did not vary much. While Bt modifications had no effect on endophytes and ectophytes and it is seen from the observations that the Bt gene had not transferred from Bt plants to associated microflora. These results represent the first evaluation of the composition of endophytic and ectophytic fungi as well as bacteria associated with transgenic cotton plants. Also detection of Bt gene in associated microflora by using Bt Express strips.
\end{abstract}

How to view point the article : Ambhore, S.N. and Barhate, B.G. (2017). Status of microflora on Bt and non - Bt cotton. Internat. J. Plant Protec., 10(2) : 448-452, DOI : 10.15740/HAS/IJPP/ 10.2/448-452. 